\title{
O vocabulário fiscal e suas práticas \\ : um estudo sobre as possibilidades de análise das dinâmicas tributárias e seus desvios (América portuguesa, séculos XVII e XVIII) ${ }^{\mathrm{I}}$
}

\author{
Letícia dos Santos Ferreira \\ Doutora em História pela Universidade Federal Fluminense (UFF)
}

\section{Resumo}

O presente artigo busca identificar a ocorrência de diversas práticas lícitas e ilícitas na América portuguesa entre os séculos XVII e XVIII relacionadas à administração fiscal com o objetivo de identificar em que medida a Coroa portuguesa buscava ou não coibir as ações ilícitas, bem como, mapear alguns dos seus significados naquela época. A pesquisa revelou uma Coroa atenta às ilicitudes. Todavia, essa atenção, no geral, tinha sentidos e significados distintos dos nossos. A pesquisa tomou como ponto de partida os documentos publicados na Coleção Documentos Históricos da Biblioteca Nacional, passando para uma análise complementar a partir dos documentos do Conselho Ultramarino disponíveis através do Projeto Resgate. A investigação também identificou que as rendas régias eram comumente associadas a tributo ou a imposto. Contudo, em certos momentos distinções mais específicas eram feitas de modo a proteger ou garantir direitos e privilégios.

Palavras-chave Tributo - Descaminho - Ilicitude - Brasil colonial.

\section{Submissão}

$25 / 07 / 2020$

Aprovação
\[ 23 / \mathrm{II} / 2020 \]
Publicação

$17 / 02 / 2021$ 


\title{
The Fiscal Vocabulary and Practices: A Study on the Possibilities of Analysing Tax Dynamics and Their Deviations (Portuguese America, 17th and I8th Centuries)
}

\begin{abstract}
This article seeks to identify the occurrence of several licit and illicit practices in Portuguese America between the 17 th and I8th centuries related to tax administration with the aim of identifying the extent to which the Portuguese Crown sought or not to curb illicit actions, as well as mapping some of their meanings at that time. The survey revealed a Crown attentive to illegality. However, this attention, in general, had senses and meanings different from ours. The research took as a starting point the documents published in the Historical Documents Collection of the National Library, moving on to a complementary analysis based on the documents of the Overseas Council available through the Rescue Project. The investigation also ended up identifying that royal rents were commonly associated with taxes or taxes, however, on certain occasions more specific distinctions were made in order to protect or guarantee rights and privileges.
\end{abstract}

Keywords Tribute - Dispatch - Illicitness - Colonial Brazil.

\section{El vocabulario fiscal y sus prácticas: un estudio sobre las posibilidades de analizar la dinámica tributaria y sus desviaciones (América portuguesa, siglos XVII y XVIII)}

\section{Resumen}

Este artículo busca identificar la ocurrencia de varias prácticas lícitas e ilícitas en América entre los siglos XVII y XVIII relacionados con la administración tributaria con el objetivo de identificar en qué medida la Corona portuguesa buscó o no frenar las acciones ilícitas, así como, mapear algunos de sus significados en ese momento. La encuesta reveló una Corona atenta a la mala marcha. Sin embargo, esta atención, en general, tuvo sentidos y significados diferentes a los nuestros. La investigación tomó como punto de partida los documentos publicados en la Coleção Documentos Históricos da Biblioteca Nacional, pasando a un análisis complementario basado en los Documentos del Consejo de Ultramar disponibles a través del "Projeto Resgate". La investigación también identificó que las rentas reales se asocian comúnmente con tributos o impuestos. Sin embargo, en ciertos momentos se hicieron distinciones más específicas para proteger o garantizar derechos y privilegios.

Palabras clave Impuesto - Descamino - Ilicitud - Brasil colonial. 
“(...) por se ajustar esta repartição com a possibilidade de cada uma, e nesta forma se continuará a contribuição, com suavidade, e sem fallencia, assentando-o VM. assim com as câmaras para que se não innove”.

DHBN, I928, v. 3, p. I22. Bahia, 7 de agosto de I65I.

\section{Introdução}

$\mathrm{O}$

fragmento de texto acima compóe uma gama de documentos que versam sobre uma antiga e complicada questão na história do Brasil: a tributação colonial. Apesar de breve, ele aponta algumas preocupações que orientavam a fiscalidade régia: a divisão entre os colonos - sugerindo a proporcionalidade -, o pagamento - que não poderia deixar de acontecer - o peso dos tributos - não deveriam provocar a falência - e, por fim, a ingerência dos poderes locais - os vereadores não deveriam mudar a forma estabelecida. Temos, portanto, referências às práticas lícitas e alertas quanto às ilícitas.

Ambas as ações eram executadas através de atos administrativos, políticos, comerciais e fiscais. Os homens eram os principais agentes e podiam ter origens sociais e atividades econômicas diversas. Sendo comum a identificação de militares, comerciantes, viajantes e membros da administração colonial participando ativamente das licitudes, mas também das ilicitudes.

Assim, como indicou Paulo Cavalcante, as ilicitudes só podem ser compreendidas quando inseridas no conjunto das práticas lícitas, ou seja, é preciso buscar compreender a ordem para abarcar com mais profundidade a desordem. Pelo mesmo raciocínio, devese buscar apreender como a desordem colaborou para a manutenção da ordem. Portanto, esse artigo procura abordar as problemáticas em torno do fisco e da corrupção de tipo fiscal na América Portuguesa, entre os séculos XVII e XVIII, atentando para as ações lícitas e ilícitas como as duas faces da mesma moeda. ${ }^{2}$

Para perceber as relações entre o legal e o ilegal, procuramos identificar como essas atitudes eram definidas e compreendidas pelos agentes coloniais. Para tanto, realizamos uma análise dos discursos observando os usos dos vocábulos tocantes às práticas fiscais lícitas e ilícitas, e, sempre que possível, suas circunstâncias de produção. Com isso, buscaremos indicar as acepções e valores normativos dos vocábulos em seu tempo, e, em diálogo com o momento presente da pesquisa. Passaremos a observar o emprego de

2 OlIVEIRA, P. C. de Jr. Negócios de Trapaça. Caminhos e descaminhos na América portuguesa (I70o-I750) São Paulo: HUCITEC, 2005. 


\section{REVISTA ANGELUS NOVUS}

alguns termos relevantes para a história da fiscalidade, analisando os seus significados dicionarizados, mas também buscando captar seus usos na prática social. ${ }^{3}$

A partir do exposto, em um primeiro momento, discorremos brevemente sobre a produção historiográfica da Nova História Fiscal, passando a uma avaliação geral da tipologia de documentos e termos elencados para a pesquisa, e por fim, analisamos alguns casos que nos ajudam a compreender um pouco mais sobre as dinâmicas fiscais no período colonial.

A Nova História Fiscal é uma corrente de estudos que se afirmou na produção inglesa, mas, sobretudo na Espanha através do Instituto de História Fiscal. Podemos dizer resumidamente que os estudos ligados a essa corrente buscam compreender o ordenamento jurídico de natureza fiscal, sua efetiva manifestação na sociedade, assim como, promover uma análise cultural da fiscalidade. Com isso, as investigações são realizadas no sentido de captar as visões de mundo, pontuando, em que sentido os regimes fiscais são ou não aceitos por determinado grupo social e de que forma esses manifestavam suas posições contrárias ou entendiam como justificável o conjunto dos tributos. Os historiadores ligados a esse campo de estudos têm se debruçado sobre os canais de negociação política que no limite podiam desdobrar-se em práticas desviantes e mesmo em revoltas e rebeliões. ${ }^{4}$

Uma problemática abordada é o papel dos subsídios e dos donativos no processo que forjou o sistema fiscal municipal no reino de Aragão em fins da Idade Média. Essas contribuições de caráter voluntário e temporário eram destinadas a fins específicos ligados à fazenda real, contudo, o estabelecimento e a cobrança tenderam a estar a cargo das câmaras. Dessa forma, contribuíram para que a tributação local se desenvolvesse na esteira da fiscalidade régia. A ampliação da capacidade de cobrar impostos e contribuições a partir do centro promoveu a formação de um aparato tributário e financeiro favorável à localidade, ou seja, aos cabildos. Os municípios não eram apenas a base do fisco régio, mas estavam inseridos em suas estratégias financeiras. ${ }^{5}$

Ainda sobre os poderes locais e a intensão régia de tributar, é preciso destacar as tensões entre os poderes tradicionais e o rei. Analisando a tributação nobiliárquica

3 KOSELLECK, R. “Uma história dos conceitos: problemas teóricos e práticos”. In: Estudos históricos. v. 5, n. IO, p. I34-I46, I992.

4 FIGUEIREDO, L. A. R. Revoltas, fiscalidade e identidade colonial na América Portuguesa. Rio de Janeiro, Bahia, e Minas Gerais, I640-176r. Tese (Doutorado). Faculdade de Filosofia, Letras e Ciências Humanas, Universidade de São Paulo, São Paulo, 1996.

5 MARTÍNEZ, M. S. "La monarquia y las ciudades desde el observatório de la fiscalidad”. In: MUÑOZ, J. A. S. (coord.) La Corona de Aragón en el centro de su historia, I208-I458. La monarquía aragonesa y los reinos de la corona. Zaragoza: Grupo de Investigación de Excelencia C.E.M.A, Universidad de Zaragoza, 2oro, p. 43-64. "Tributos Negociados: las questie/subsidios de las villas catalanas en le primera mitad del siglo XIV". In: Anuario de Estudios Medievales. v. 38, n. I, 2008.

$4 \cdot$ ano XII, n. I7, 202I • ISSN 2179-5487 
espanhola, percebe-se que a nobreza não tinha capacidade para criar novas figuras fiscais, da mesma forma que a coroa tinha enorme dificuldade em impor reformas ou novas contribuições. Tais dificuldades decorriam, principalmente, da pressão imposta pelos grupos beneficiários dos sistemas fiscais vigentes no século XVII. Assim, a Coroa tendeu a negociar os encargos e compensaçóes com cada membro dos estamentos privilegiados do que coletivamente nas cortes. ${ }^{6}$

A tradição de estudos sobre a fiscalidade colonial remonta aos fins do século XIX. Todavia, em grande medida, essa produção observou a dinâmica do fisco a partir da perspectiva nacionalista, esforçando-se para comprovar a eficiência e a opressão metropolitana sobre a sociedade colonial.7 Alguns trabalhos mais recentes, desde os meados do século $\mathrm{XX}$, produziram análises de caráter mais sistemático, abordando séries completas de arrecadação de tributos, especialmente, em Minas Gerais. A centralidade dessa capitania nos estudos tributários permanece hoje, mas os objetos analisados diversificaram-se. Há pesquisas desenvolvidas sobre os contratos, os contratadores, a administração fazendária, suas instituições, tributos e revoltas. Conjugando essas duas últimas temáticas, destacamos os estudos de Luciano Figueiredo que examinou a política fiscal através das revoltas. Os motins são apresentados como desdobramentos das disputas entre grupos sociais e alterações conjunturais, provocados muitas vezes por divergências entre culturas políticas distintas. ${ }^{8}$

No tocante à temática da corrupção ou da fraude enquanto um elemento constitutivo do fisco, verificamos duas formas de abordá-la. A primeira ocorre através da análise do discurso coetâneo sobre o direito de descaminhar como uma resistência à opressão régia e a segunda destaca a questão discorrendo sobre as suas especificidades no mundo colonial.

A fraude poderia ocorrer em maior ou menor grau de acordo com a autonomia na administração dos impostos, o que por sua vez gerava um conjunto de políticas fiscais

6 SALAS, L. A. "La fiscalidad, el estado moderno y la historiografia nobiliária: estados fiscales y nobleza castellana (siglos XVI y XVII)”. In: Tiempos Modernos. Revista Electrónica de Historia Moderna. vol. 3, no 8, 2003. ___ (org.) Los âmbitos de la fiscalidad: fronteras, territorio y percepción de tributos en los imperios ibéricos. (siglo XV-XVIII). Madri: Ministerio de Economía Y Havienda, Instituto de Estudios Fiscales, 20 II.

7 SANTOS, F. Memórias do distrito diamantino. Belo Horizonte: Itatiaia, 1975. João Pedro Xavier da VEIGA, J. P. X. Efemérides mineiras. Ouro Preto: Imprensa Oficial, I896. LYRA, M. L. V. Os dízimos reais na capitania de São Paulo: Contribuição à História Tributária do Brasil Colonial (1640-1750). Dissertação de Mestrado. São Paulo, 1970. GUIMARÃES, M. "Contratos e Conluios: a administração fazendária no Rio de Janeiro”. Revista da Sociedade Brasileira de Pesquisa Histórica, v. 2I, Curitiba, p. 4I-49, 200I. MAXWELL, K. $A$ devassa da devassa. A Inconfidência Mineira: Brasil e Portugal 1750-I808. São Paulo: Paz e Terra, 200 . FURTADO, J. F. O Livro da Capa Verde. O Regimento Diamantino de I77I e a Vida no Distrito Diamantino no Periodo da Real Extração. São Paulo: Annablume, 1996. OSÓRIO, H. O Império português: no sul da América - estancieiros, lavradores e comerciantes. Porto Alegre: Editora da UFRGS, 2007. LAMAS, F. G. Os contratadores e o Império colonial português: um estudo dos casos de Jorge Pinto de Azevedo e Francisco Ferreira da Silva. Dissertação de mestrado. UFF. 2005. 


\section{REVISTA ANGELUS NOVUS}

localmente diferenciadas. A diversidade de práticas fiscais ao atender às especificidades locais acabava por abrir margem para uma gestão mais ou menos rígida e, assim, mais ou menos propícia à fraude. Outro impacto dessa geografia heterogênea da fiscalidade era o desvio dos fluxos comerciais de uma área para outra. Uma geografia tributária diversa motivava os comerciantes a buscarem áreas com uma tributação menor, gerando assim uma série de problemas como o desabastecimento e a carestia. ${ }^{9}$

Assim, a fraude resultava da própria estrutura do fisco régio que era recente, autônoma e descentralizada e não por uma conduta imoral ou contestadora por parte dos indivíduos ou dos grupos. Todos podiam fraudar, contudo, eram exatamente aqueles que podiam contribuir com maiores somas para o fisco real que conseguiam fraudar em maior medida, provocando uma sobrecarga aos demais. Os vassalos e as cidades apresentavam a desobediência fiscal como um direito com base em seus supostos privilégios e isenções. Os senhores e cavaleiros eram os que mais sonegavam e usavam os costumes como argumento para justificar suas condutas. A Coroa, por sua vez, não tinha uma atitude passiva em relação às práticas desviantes. Ao contrário, seguia desempenhando uma atitude combativa com o intuito de obter mais recursos. ${ }^{10}$

No espaço colonial português, temos uma situação similar. Os desvios da fazenda real eram realizados, principalmente, pelos grupos mais privilegiados, incluindo até mesmo os representantes régios. Esses agentes, ao descaminharem acabavam por reforçar, e não negar, o sentido da colonização. O descaminho dos tributos, das contribuições e dos direitos régios eram a outra face da moeda colonial, ou seja, da exploração e exteriorização das riquezas ainda que por outro caminho que não o da fazenda real. Além da sonegação havia o desvio de parte dos pagamentos, aumentando a diferença entre o tributo pago e o recolhido pelos cofres régios. O recurso era extraviado do seu percurso, mas seu destino continuava o mesmo, indo parar nos bolsos e cofres de “nobres cidadãos de bem” na Europa. É claro que a Coroa estava atenta e procurou agir no sentido de coibir essas práticas, que, por sua própria natureza ilícita, não costumam deixar muitos rastros e se podemos identificá-las é exatamente porque de algum modo havia uma tentativa de impedi-las de ocorrerem. ${ }^{\text {II }}$

9 PEREZ, José Fortea. "Economía, arbitrismo y politica en la Monarquia Hispánica a fines del siglo VI". Manuscrits. Revista d'Història moderna. Barcelona, Universidad de Barcelona, 1998, p. 155-176.

Io PÉREZ, J. I. F. "Aproximación al estudio de las actitudes sociales ante el fisco: el fraude fiscal en la corona de castilla en el siglo XVI”. In: Studia Historica. História Moderna. Salamanca, 1987, p. 99-IIo. GEA, B. C. Fraude y desobediencia fiscal en la corona de Castilla en el siglo XVII, (I62I-I700). Valladolid: Junta de Castilla Y León, Consejería de Educacíon y Cultura, 2000.

iI OLIVEIRA, P. C. de Jr. Negócios de Trapaça. Caminhos e descaminhos na América portuguesa (1700-I750). São Paulo: HUCITEC, 2005.

$6 \bullet$ ano XII, n. I7, 202I • ISSN 2I79-5487 
Por um lado, as ações corruptas praticadas por membros das elites locais, que podiam ou não ocupar cargos na governação, era facilitada pela indistinção entre público e privado. Por outro, funcionavam como uma fronteira social, ou seja, a maior ou menor tolerância ao delito dependia do lugar social de quem o praticava. ${ }^{\mathrm{I2}}$ Mas o contrabando nem sempre deve ser entendido como um entrave aos interesses monárquicos ou dos demais agentes da colonização. Roquinaldo Ferreira identificou a importância do contrabando para a viabilidade do próprio tráfico de escravos, uma vez que o comércio dos panos da Índia, da cachaça, do ouro e do tabaco nem sempre eram permitidos pelas autoridades portuguesas na Costa Africana, seja aquele realizado com os próprios africanos ou com comerciantes holandeses ou ingleses. ${ }^{13}$

Em meados de 2017, Adriana Romeiro lançou um livro sobre corrupção na época colonial, evidenciando a atualidade da temática. Ao encarar o desafio de analisar a corrupção em sua dimensão histórica, a autora não produziu uma genealogia das práticas ilícitas, ao contrário revelou a historicidade e aplicabilidade do conceito no mundo português e em seus territórios ultramarinos. Discorrendo sobre as convenções teóricas da época, mas também sobre a prática governativa, Romeiro deixou claro que havia uma condenação às ações que levavam à corrupção do bem comum.14

É importante ressaltar a desnaturalização da corrupção. As atitudes corruptas nem sempre existiram, nem tão pouco são uma tendência inata à humanidade. Menos ainda, resultam de um suposto instinto de sobrevivência. As práticas desviantes possuem historicidade. Em cada sociedade, em diferentes espaços e temporalidades, elas podem ocorrer ou não, com maior ou menor intensidade, tendo significados diversos na configuração dos jogos políticos e econômicos. Desse modo, é de fundamental importância examinar o discurso e as palavras que o compõe em relação ao contexto e, quando possível, aos propósitos de sua produção.

Em um movimento dialético, propomos refletir acerca das palavras e das coisas, das palavras e das práticas, trabalhando com documentos de caráter administrativo, portarias, consultas, ordens, provisões e cartas. A análise da documentação buscou identificar os discursos codificados e regulamentados enquanto uma linguagem política comum. Atentaremos para as formas que as falas assumem no ambiente de seus interlocutores, pois nos interessa não apenas o que os textos dizem, mas as

I2 KÜHN, F. "Os interesses do governador: Luis Garcia de Bivar e os negociantes da Colônia do Sacramento (1749-1750)". Topoi, v. 13, n. 24, p. 29-42, 2012.

I3 FERREIRA, R. "A arte de furtar: redes de comércio ilegal no mercado imperial ultramarino português (c. I690-c.I750)". In: João Fragoso e Maria de Fátima Gouvêa (orgs.). Na trama das redes: política e negócios no império português - séc. XVI-XVIII. Rio de Janeiro: Civilização Brasileira, 20Io, p. 203-242.

I4 ROMEIRO, A. Corrupção e poder no Brasil. Uma história, séculos XVI a XVIII. Belo Horizonte: Autêntica Editora, 2017. 


\section{REVISTA ANGELUS NOVUS}

circunstâncias nas quais foram ditos, e quem disse. Os enunciados não são inocentes e, por isso, revelam estruturas mentais, capazes de perceber e organizar a realidade. Dessa forma, verificar a recorrência e o uso dos vocábulos relacionados à temática fiscal pode nos ajudar a compreender a relação entre texto e contexto, permitindo entender melhor a fiscalidade. Para tanto, é fundamental, observar como os interlocutores - senhores de engenho, comerciantes, vereadores, governadores, conselheiros e demais agentes políticos - exploram as regras e atuam sobre elas a fim de mantê-las ou alterá-las. ${ }^{\text {Is }}$

A principal ferramenta utilizada nessa pesquisa foi a Hemeroteca digital da Biblioteca Nacional. Nela estão disponíveis os volumes da coleção Documentos Históricos, sendo possível realizar buscas por palavras. Através do endereço eletrônico dessa biblioteca, também tivemos acesso aos documentos do Arquivo Histórico Ultramarino. Outro instrumento importante foi o dicionário escrito por Raphael Bluteau, ainda no século XVIII. ${ }^{16}$

A pesquisa valeu-se de expressóes relativas ao ordenamento fiscal, tais como direitos (4210), arrecadação (2834), arrematação (1907), donativo (1793), dízima (679), descaminhos (IIOI), subsídio (678), quinto (635), imposto (59I), tributo (522), dízimo (514), finta (389), descaminho (343), descaminhar (35), desvio (40), desviar (40), fisco (332), fiscal (329), capitação (318), sisa (2I2), redízima (I34), fraude (s) (192), fraudar (I4) corrupção (77), sonegação (13), sonegar (2), tributar (9). O total de mais de dois mil documentos, por um lado, coloca em evidência a potência dos acervos selecionados para os estudos sobre fiscalidade no período colonial, por outro, impõe a necessidade de privilegiarmos alguns pontos em detrimento dos demais. Dados os limites desse artigo, optamos por selecionar os seguintes termos: imposto, tributo, corrupção, desvio, sonegação, fraude e descaminho. Nossa proposta é abordar, por um lado palavras que remetem diretamente ao ordenamento fiscal, por outro, selecionamos termos associados à desordem, ou, às práticas ilícitas. Compreendendo que há entre eles uma organicidade. ${ }^{17}$ (org.). Por uma História Politica. Rio de Janeiro: FGV, 2003, p. 295 -230.

I6 BLUTEAU, R. Vocabulario portuguez ES latino (...) Lisboa: Collegio das Artes da Companhia de Jesus, Officina de Pascoal da Sylva, I7I2-I728. 8 v. 


\section{Das palavras e das coisas}

A estruturação do Estado Moderno teve como um dos seus pilares o desenvolvimento da fiscalidade..$^{18}$ Obviamente, o problema do gerenciamento fiscal não era uma novidade àquela altura. Contudo, a fiscalidade, no mundo português, ganhava cores específicas com o processo de Expansão Marítima, em especial no tocante aos movimentos das alfândegas. Mas, o fisco régio não se fez apenas por elas. Além dos direitos de entrada e saída das mercadorias das Índias, dos escravizados, do tabaco, do açúcar e demais produtos de além-mar, também chegavam aos cofres reais diversos outros tributos, seja na forma de impostos, seja como contribuições voluntárias.

A fiscalidade não seguiu um caminho linear, variando ao longo do tempo, como por exemplo, em situações belicosas, quando a Coroa portuguesa acabava por depender mais das rendas do reino. Tal situação ficou muito evidente durante as guerras de Restauração, ainda que como afirmou Stuart Schwartz, a prata, o açúcar e os escravos tenham restaurado Portugal, as guerras no Atlântico ou no Tejo dificultaram o movimento nas alfândegas nas primeiras décadas do seiscentos. Por outro lado, com a recuperação do comércio ultramarino e a recomposição das rendas alfandegárias na segunda metade do século XVII, o reforço tributário foi mais significativo, especialmente pelo aumento do peso dos impostos indiretos e das solicitações de contribuições voluntárias. Nosso trabalho debruça-se exatamente sobre esse contexto. ${ }^{19}$

No Estado do Brasil, em termos geográfico, os impostos variaram de capitania para capitania, sendo o dízimo o principal tributo cobrado pela Fazenda Real, ao menos até I70o. Quanto ao aspecto cronológico, é digno de nota que as buscas acerca do termo imposto na Coleção Documentos Históricos tenham seus resultados concentrados nos documentos produzidos nas décadas finais do século XVII e nas primeiras do seguinte. O aumento da carga tributária é confirmado também pelo aumento das despesas, uma vez que a estrutura fiscal seiscentista foi marcada pelo contingenciamento. Buscava-se aumentar as receitas à medida que as despesas cresciam..$^{20}$

Quanto ao uso da palavra imposto, verificamos que esse varia entre o adjetivo e o substantivo. No primeiro caso, refere-se àquilo que foi imposto como o foro ou a pena, ou mesmo, uma nova tributação. No segundo, como um tipo específico de tributo, tal

I8 De maneira geral, podemos afirmar que outros elementos centrais foram: a aplicação impessoal das leis no conjunto da população; definição de propriedade privada separada do domínio público; mudanças no código penal, tendendo ao encarceramento e ações cerceaduras controladas pelo Estado, bem como a formação de um exército permanente e disciplinado. 


\section{REVISTA ANGELUS NOVUS}

como o imposto do sal, imposto dos escravos, ou novo imposto dos vinhos, da aguardente e do tabaco e, ainda, o novo imposto para o donativo dos príncipes. Parecenos seguro afirmar que o uso do substantivo passa a ser recorrente apenas nos documentos a partir de 1660, havendo uma concentração entre as décadas de 1680 e I690, e amplo uso nas duas primeiras décadas de I700. Especialmente no Arquivo Histórico Ultramarino são raras as ementas que usam o termo. No caso do Rio de Janeiro, há apenas dez ocorrências da palavra imposto para o século XVII, dentro de um conjunto de 42 documentos. Nos avulsos da Bahia, o documento mais antigo que possuí em sua ementa o termo imposto data de 1722.

Chamou a nossa atenção o uso do qualificativo "novo". A concentração dos documentos com essa expressão pode sugerir um incremento das práticas tributárias, ou mesmo uma ampliação da jurisdição fiscal. Isso porque "novo" é aquilo que foi feito a pouco tempo, mas também o que ninguém fez. Assim, os novos impostos podem tanto ser o resultado de uma alteração em uma tributação antiga ou de fato o fisco ampliando suas garras sobre outros produtos. Assim parece ter ocorrido com o imposto do sal. Desde 1632, o sal era tributado para o sustento das guarnições militares. Contudo, em 1692, a Câmara do Rio de Janeiro e o padre Francisco de Matos questionaram o acréscimo de quatro vinténs sobre o alqueire de sal, agora, para compor o soldo dos governadores. ${ }^{21}$

Há ainda uma terceira possibilidade: o imposto pode ser identificado com o termo "novo", sendo esse usado como um substantivo e não como uma qualidade. Esse parece ser o caso do "novo imposto da Villa de Santos" que recaiu sobre as bebidas a partir de 1704, mas continua sendo assim chamado, ao menos até $1738 .{ }^{22}$

O elemento lexical imposto foi associado em diversas situações ao termo tributo. Esse, por sua vez, significava uma contribuição geral de um estado - grupo social - a um príncipe em virtude de um acordo que fizeram entre si para os gastos da Coroa. Definido por um período determinado, acabava por se tornar ordinário. O tributo era arrecadado aos povos de acordo com as suas posses ou podendo ser pago "pela mercancia”, admitindo isenções e devendo ser sempre cobranças justas. Porém, alertava o padre Raphael Bluteau, quando as cobranças fossem pesadas demais, deveria o súdito "beijar a vara com que o príncipe o açoita e deixar o castigo a Deus" ${ }^{23}$

O significado dicionarizado por Bluteau, igualmente, apontou uma relação direta entre imposto e tributo, contudo, a prática tendeu a associar o último a outra figura 2I BIBLIOTECA NACIONAL. Documentos Históricos da Biblioteca Nacional (DHBN). Rio de Janeiro: Biblioteca Nacional, 1951, v. 63, p. 58-60.

22 DHBN. Rio de Janeiro: Biblioteca Nacional, v. I, p. 337 e 367.

23 BLUTEAU, op. cit., v. 8, p. 28I-282.

Io $\bullet$ ano XII, n. I7, 202I • ISSN 2179-5487 
fiscal: donativo. Sendo mencionado por mais de 330 vezes nos Documentos Históricos, identificamos que na maioria das vezes - em torno de 190 ocorrências - está relacionada aos forais de concessão de sesmarias. Sendo a aparição mais tardia do ano de 1534, data marco da constituição das capitanias hereditárias. Nesses casos, foi usado para marcar a isenção fiscal: "assim dareis livremente sem outro algum foro, nem tributo somente o dízimo à ordem de Nosso senhor Jesus Christo”. Em outros, surgiu acompanhado do sal, vinho, tabaco, aguardente e papel selado, ocorrendo, principalmente, entre 1660 e I720.

Todavia, nesse contexto, tributo estava sendo usado para nomear ações relativas ao donativo para o dote da sereníssima Rainha da Grã-Bretanha e para a Paz com a Holanda. Solicitada no contexto das guerras de Restauração, o pagamento deveria ser livre e expressar o amor dos súditos pelo monarca e por sua irmã, a Rainha da GrãBretanha, Catarina de Bragança. A associação repete-se, em menor frequência, com a nova solicitação de 1725 , dessa vez, para o casamento dos príncipes Maria Bárbara de Bragança e D. José I, respectivamente casados com os espanhóis Felipe V e Mariana Vitória de Bourbon. Igualmente inserido em um cenário belicoso, nesse caso da Guerra de Sucessão Espanhola, o subsídio para o duplo casamento era também uma contribuição voluntária.

Considerando, de forma geral, o termo "tributo" para nomear um conjunto amplo de contribuições fiscais, não há neste momento uma consideração mais específica a ser feita. Exceto, no caso dos donativos. Isso ocorre pelo fato dos próprios sujeitos históricos pontuarem a distinção entre os dois. ${ }^{24} \mathrm{Na}$ Câmara de São Paulo, os oficiais ao agradecerem o esforço régio por determinar a prorrogação do pagamento do donativo do dote de Catarina de Bragança e paz de Holanda, reafirmaram o compromisso em pagar o "pedido real". Porém, reunidos na casa da Câmara, vereadores e povo lembraram que faziam "por título de pedido; e não tributo". 25

Em sentido similar, posicionou-se o procurador da fazenda no Conselho Ultramarino na consulta datada de 22 de fevereiro de 1734 : "Que os povos concordaram neste donativo não houvesse privilegiado, porque não era tributo, mas sim uma oferta que os vassalos faziam ao seu rei para as despesas dos desposórios dos sereníssimos príncipes”. Os donativos eram figuras fiscais com uma série de especificidades: temporários, proporcionais, voluntários e gerais. Assim, eram diferentes de tributos.

24 FERREIRA, L. S. É Pedido, não tributo. O donativo para o casamento de Catarina de Bragança e a paz de Holanda (Portugal e Brasil c. I66o-c. I725). Tese (Doutorado) - Universidade Federal Fluminense, Instituto de Ciências Humanas e Filosofia, Departamento de História, 2014.

25 ACMSP. Requerimento que fez o povo e moradores desta vila de São Paulo e os mais assistentes nesta vila aos senhores oficias da câmara desta vila de São Paulo acerca dos a oito anos que se deram demais. São Paulo, I2/II/I667. v. 6 - Anexo. p. 550-55I. 


\section{REVISTA ANGELUS NOVUS}

Não cabia isenção, tinham um prazo para acabar e não eram uma obrigação, mas uma doação ao rei. E assim como demonstramos em outro momento, tornaram-se instrumentos para a Coroa ampliar os sujeitos inseridos em sua política fiscal. ${ }^{26}$

No dia a dia, o uso das palavras podia assemelhar coisas distintas, mas havia uma noção compartilhada de que os termos expressavam ideias que podiam ser opostas. $\mathrm{O}$ uso de uma ou de outra palavra podia indicar.

Para pensar as ilicitudes, comecemos pela palavra "corrupção". Segundo Bluteau, corrupção significava "suspensão do concurso conservativo, e introdução de qualidades alterantes, e destrutivas”. ${ }^{27}$ A corrupção podia ser dos costumes, que significava depravação, grandes desordens. Podendo existir a do juiz ou a da própria justiça. Corrupto era aquele indivíduo viciado, danado, depravado, corrompido no sentido natural e moral.

Evidentemente, os usos de um termo não se limitam às acepções dispostas em um dicionário. Por isso, Adriana Romeiro elaborou um estudo significativo "indagando a realidade que ele recobria" em língua castelhana e portuguesa. A autora concluiu que:

Se a noção de corrupção, no sentido de desvio moral ou político, não era estranha ao imaginário político da Época Moderna, é de se notar, porém, que ao contrário do uso atual da palavra, que recobre as práticas, confundindo-se com elas, as práticas não eram consideradas em si corruptas: elas desencadeavam o processo de corrupção da República. É a partir do final do século XVIII que a palavra sofre um crescente deslizamento semântico, tornando-se, aos poucos, sinônimos de práticas corruptoras. ${ }^{28}$

Romeiro aceita o uso do conceito de corrupção para nomear os efeitos de práticas que prejudicariam a república, aceitando a ideia de sociedade enquanto um corpo, sujeito às enfermidades e aos remédios. Por um lado, destaca a atenção dada ao tema por certa historiografia, ${ }^{29}$ por outro, chama a atenção para um certo silenciamento nos estudos mais recentes, em especial acerca do enriquecimento ilícito. Para a autora, o pouco avanço acerca dessa problemática deve-se à grande centralidade dos estudos acerca do sistema de mercês. A historiografia luso-brasileira, ao destacar as recompensas institucionais, acaba por dar pouca atenção à força de atração que as vantagens extras poderiam exercer nos agentes coloniais. Ainda que os referidos ganhos nem sempre fossem vistos como atos que corrompessem a república, estudá-los seria extremamente elucidativo para a compreensão da realidade colonial.

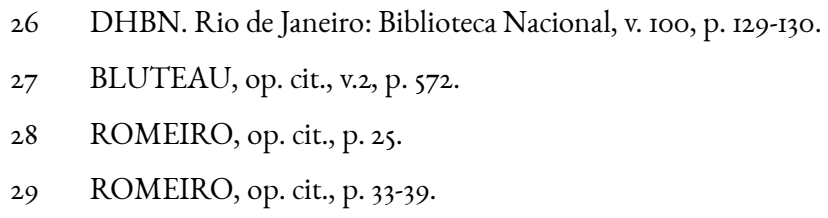


Essa problemática se revelou bem interessante em nossa investigação. Encontramos apenas 77 alusões ao termo e o uso referia-se sempre ao processo de deterioração de uma matéria orgânica. A Coroa parecia preocupada com a conservação das mercadorias. Essa preocupação revelava uma inadequada estrutura alfandegária que impunha como solução vender o mais rápido possível os bens depositados nos portos, seja por arribadas ou confisco.

A situação repete-se nas buscas realizadas nos documentos do Arquivo Histórico Ultramarino. Nesse conjunto, encontramos uma recorrência um pouco maior, contudo, a maioria absoluta estava fora do nosso recorte cronológico. No período em estudo, a palavra corrupção era usada no mesmo sentido encontrado no DHBN. Todavia, a palavra foi usada nas ementas produzidas posteriormente pelos arquivistas, e não no documento propriamente dito. A curiosidade nos impulsionou a observar brevemente as fontes posteriores e arriscamos dizer que apenas na documentação referente à Revolução Pernambucana encontramos a palavra corrupção ligada à ideia de ilicitude.

Vejamos alguns casos. Em fevereiro de 1738, a carta enviada às fortificações orientava que os armazéns fossem abertos ao menos uma hora a cada dois dias para que os produtos que ali estavam não recebessem “corrupção”. Para as vilas de Santos, São Paulo e São Vicente, igualmente, temos uma atitude preventiva em relação à corrupção dos mantimentos, dessa vez expostos demais ao tempo. O Vice-rei Vasco Fernandes Cesar de Menezes havia sido aconselhado, em I722, a por em hasta pública os gêneros confiscados que fossem "sujeitos a corrupção". ${ }^{30}$

Ao mesmo tempo que percebemos a acepção da palavra, a discussão acima nos permite discorrer sobre as condições de armazenamento dos portos coloniais e as circunstâncias materiais para aplicar a fiscalidade. A precária estrutura da Casa da Alfândega descrita por Hyllo Salles, Grazielle Casimiro e Paulo Cavalcante fica aqui evidente. A falta de espaço para acondicionar as caixas, as condições para preservar os produtos, e a ausência de oficiais suficientes permitiam a exposição dos bens ao tempo e às pessoas mal-intencionadas. ${ }^{3 \mathrm{I}}$

DHBN. Rio de Janeiro: Biblioteca Nacional, v. I, p. 317-32I, I928. . v. 3, p. 16-19, 1928. v. 6, p. $434,1928$.

3I OLIVEIRA JR, P. C. e CARDOSO, G. C.. "Estrutura e dinâmica da fiscalização e arrecadação do direito da dízima da Alfândega da cidade do Rio de Janeiro, I70o-I725” In: CARRARA, A. A. e OLIVEIRA JR, P. C. As alfândegas do Brasil. Rio de Janeiro e Salvador, século XVIII. Estudos de administração fazendária. Juiz de Fora, 2016, p. 23-53. SALLES, H. N. A. Negócios e negociantes em uma conjuntura critica: o ponto de Salvador e os impactos da mineração, I697-I73I. Dissertação (Mestrado). Juiz de Fora, Universidade Federal de Juiz de Fora, 20I4. 


\section{REVISTA ANGELUS NOVUS}

O tempo agia, tanto no sentido das condições atmosféricas, como temperatura e umidade, que podiam corromper os materiais, quanto no que diz respeito ao período transcorrido entre a chegada e a partida de um navio. Nessas circunstâncias, quanto maior o período de permanência de uma embarcação no porto, maiores as oportunidades de pôr em prática os descaminhos. Em outra, a pressa em partir, dificultava a averiguação das cargas e a quitação dos tributos, uma vez que o edifício era pequeno e os agentes eram poucos. ${ }^{32}$

Corrupção dos materiais, roubos, sonegação, descaminho, desvios, de um tudo podia ocorrer nas pequenas e desguarnecidas alfândegas coloniais. Para alguns, ampliar a casa parecia uma solução óbvia e urgente, enquanto para outros "nenhuma diligência era bastante". ${ }^{33}$ Haveria uma forma eficiente de combater as práticas ilícitas? Estavam adulando ao rei ou sendo práticos? $\mathrm{Na}$ alfândega do Rio de Janeiro, buscou-se executar a obra de ampliação da Casa da Alfândega, bem como introduzir novos mecanismos de cobrança de tributos, em especial da recém-criada dízima da alfândega. Essa ficou a cargo de um contratador que em suas ações estendia os braços régios, dividia os bônus e os ônus da tributação.

Dando seguimento à investigação, vejamos os resultados para a forma verbal de corrupção. Para “corromper” encontramos somente oito referências nos dois conjuntos documentais. Entretanto, a análise dos documentos revelou-se bastante interessante uma vez que surgiram três aplicações sugestivas. Na primeira, falava-se em ministros, oficiais e soldados corrompidos, depois, do poder do luxo em corromper a todos. Por último, encontramos desembargadores suspeitos de serem corrompidos por amizade ou proveito. Assim, em um universo geral de 88 ocorrências, temos somente três aplicadas ao contexto político. Estariam essas relacionadas de alguma forma às práticas fiscais?

No tocante aos desembargadores Luiz da Gama e Antonio Quintadilha, o problema era a proximidade entre esses e o réu. Gama e Quintadilha eram vistos frequentemente em rodas de conversas noturnas no terreiro de João Mascarenhas. Alegava-se mesmo que Antonio Rego Quintadilha vivia na casa de Mascarenhas. A ideia de corrupção aqui está relacionada a uma falta de isenção na condução do juízo. Como mostrou Stuart Schwartz, o abrasileiramento da burocracia, ou seja, a associação dos desembargadores e ouvidores com parcelas da comunidade soteropolitana foi uma questão central, resultando na suspensão do Tribunal da Relação. Tendo claros efeitos agosto de 1720. Códice 8o, v.r, fl. 8Iv-82v. Apud: OLIVEIRA JR, P. C. e CARDOSO, G. C., op. cit., p. 43.

I4 • ano XII, n. 17, 202I ・ ISSN 2179-5487 
na dinâmica política colonial, a corrupção dos desembargadores, em tela, não implicava necessariamente na dinâmica fiscal. ${ }^{34}$

No contexto da Guerra dos Mascates, a ação por interesse ou amizade em favor de alguns e em detrimentos de outros estaria relacionada à atitude de alguns soldados que atacaram Recife. Pois, para o governador da Bahia, a rebelião dos militares contra o governador, no Recife, teria ocorrido porque os soldados estariam corrompidos pelas dádivas oferecidas, e não por nenhuma convicção.

Em outro momento, Wenceslao da Silva reflete sobre a ruína dos gêneros - açúcar e tabaco - do Brasil e faz uso do termo corrupção como uma consequência do desejo pelo luxo, podemos dizer, pela riqueza. Assim assevera em seu texto que

Teve o luxo seu princípio no original pecado e he um mal tão calamitoso e coevo ao mundo, que quase nasceu com ele e degenerou em mortal contagio para inficionar e corromper a todos os que se alimentam deste veneno, cujo maligno efeito, irremediavelmente, sentiram muitas monarquias e republicas, que enfermando do mesmo mal, inteiramente acabaram. ${ }^{35}$

Por esse trecho, podemos perceber que sua compreensão acerca da corrupção se aproximava de uma noção de alteração do estado normal das coisas. Há um julgamento moral. O luxo, ou em outro trecho, a fama e a cobiça despertadas pelos tesouros - que por ordem divina estiveram por tanto tempo escondidos - desviaram o curso natural das coisas, colocando em risco a monarquia. Dessa forma, como um veneno que alcança a corrente sanguínea, e corrompe o corpo humano, o luxo corrompe o corpo político. A corrupção é uma consequência e não um ato em si. Logo, está empregada no sentido similar ao de putrefação, de modificação, e não de suborno como nos dois casos anteriores.

Ainda temos a consulta feita pelo Marquês de Angeja para ser analisada. Nessa, o ato de corromper foi visto como causa primeira dos males da Fazenda Real. Os conselheiros discutiam sobre a obrigação de dar acolhimento às embarcações com problemas para continuar a navegação. Era consenso que todos estavam obrigados a aceitar os navios que precisavam de socorro em seus portos, dando-lhes o que fosse necessário para retomarem seu caminho. Todavia, a discussão era intensa quanto à permissão dada aos estrangeiros para comercializarem durante a arribada. O comércio permitiria que tivessem recursos para pagarem os reparos e mantimentos obtidos nos portos do Brasil. Tal situação, alegavam os conselheiros, permitiria o escoamento de ouro para outras nações, e na perda de receitas alfandegárias. A redução dessas receitas

34 DHBN. Rio de Janeiro: Biblioteca Nacional, v. 69, p. I23-I47, I945.

35 ARQUIVO HISTÓRICO ULTRAMARINO (AHU). Bahia. Cx. 3. Doc. 347. Bahia, I2/I2/I738. 


\section{REVISTA ANGELUS NOVUS}

advinha da queda na venda dos produtos portugueses, bem como por gerar mais oportunidades de se burlar o fisco.

O efeito era significativo. Consta na consulta uma projeção de perdas de $26 \%$ do que se deveria pagar nas alfândegas e consulados em Portugal, e ao menos Io\% do comércio com o Brasil. O grande problema era a oportunidade criada e o interesse dos ministros que se deixavam corromper. ${ }^{36}$ Para os conselheiros haveria uma obrigação moral em dar socorro, mas esse poderia ser pago em formas de letras de câmbio, sem necessidade de estrangeiros realizarem comércio na América Portuguesa. Pois, uma vez permitindo o comércio necessário ao pagamento dos custos, abria-se a possibilidade de comercializar muito além do previsto. Aqui os atos dos estrangeiros implicavam tanto em contrabando, como em sonegação e corrupção. Isso porque, vendia-se produtos proibidos, omitia-se as quantidades e concedia-se dádivas aos que deviam fiscalizar para que não o fizessem.

Logo, percebemos que para o termo em análise há uma coexistência de diferentes sentidos em uma mesma realidade, sem que isso signifique uma recorrência equiparada, sendo raro o uso do termo corrupção para abordar os desvios fiscais.

Nos usos e acepções da palavra fraude, a análise das formas parece mais simples. Ao longo do tempo, o termo é usado com praticamente o mesmo significado e em condições similares. Fraudar era engano oculto, com dolo e sutileza. Fraudava aquele que tirava dinheiro ou bens do caminho da fazenda real, por conseguinte, transgredia a ordem, agia de forma ilícita. Assim foram definidas as atitudes dos paulistas em Pernambuco, no ano de 1707. Desde a segunda metade do século XVII, os milicianos de São Paulo eram convocados pelos governadores da Bahia e Pernambuco para combater os bárbaros e os quilombolas. Os paulistas, como sabemos, foram os principais responsáveis pela destruição de Palmares e da vitória colonial na Guerra dos Bárbaros. ${ }^{37}$ Todavia, as benesses conquistadas pelo bom serviço ao monarca não pareciam ser suficientes. Como foi alertado por Sebastião de Castro Caldas, governador de Pernambuco, havia "muito grande descaminho nas pagas que se fazem; porque quasi todas são fantásticas, convém muito ao serviço do dito senhor, e a boa arrecadação de sua fazenda real que Vossa Senhoria mande examinar este negócio com exação que convém”.$^{3^{8}}$ Soldados fantasmas aumentavam as despesas da fazenda régia em favor de ganhos privados de capitães e soldados. Especialmente, porque a receita só era definida depois de estabelecida a despesa.

\footnotetext{
36 DHBN. Rio de Janeiro: Biblioteca Nacional, v. 96, p. 175-187, 1952.

37 PUNTONI, P. A guerra dos bárbaros. São Paulo: Fapesp/Hucitec/Edusp, 2002.

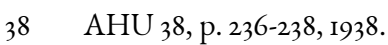

I6 - ano XII, n. 17, 202I • ISSN 2I79-5487 
Ao contrário do que ocorre hoje, não havia uma previsão orçamentária. Para cada despesa era criada uma receita específica. Em alguns casos, prorrogava-se uma receita consignando-a a outra causa. Em outros, a discussão para definir a forma para alcançar o recurso era iniciada quando a necessidade já existia. Nesse tempo, os soldados ficavam sem seus soldos e fardas, dotes eram parcelados, cartas de crédito e empréstimos eram lançados sobre a população.

Quanto à atuação dos paulistas na Capitania do Rio Grande sabemos que ficaram ao menos dois anos sem receber por seus serviços. O envio do dinheiro pelo governador da Bahia era feito através de vários homens de negócios diferentes. Essa era uma estratégia para tentar conter as perdas caso houvesse algum contratempo ou descaminho. Assim, dificilmente o montante seria completamente perdido. Todavia, a condução descentralizada dos recursos para pagar os soldados e demais homens acabava por sujeitar os mesmos a interesses nem sempre convergentes com os da monarquia.

A visão do Governador de Pernambuco, Sebastião de Castro e Caldas sobre os terços dos paulistas é ilustrada pelo provérbio português “é que cá e lá, más fadas há”. Expressão hoje com pouco uso, queria dizer sobre o excessivo número de matrículas, diante do número real de soldados. Em sentido similar, a expressão foi usada por Camões para se referir a sua experiência na sociedade indiana. Escreveu o mestre da literatura portuguesa: "pera aviso de alguns aventureiros que cuidam que todo o mato é orégãos, e não sabem que cá e lá más fadas há”. Da mesma maneira que Camões, Castro e Caldas estava atento às falsificações. ${ }^{39}$

Falsificar listas e produtos e ocultar objetos eram práticas tomadas como incorretas, fraudulentas. A ideia de ocultação, por sua vez, remete-nos a outro item da nossa pesquisa, a sonegação. Observemos a frequência e usos do verbo "sonegar” e suas variantes temporais e nominais aplicadas para se referir ao ato de não declarar os bens diante da obrigação de fazê-lo, seja mediante a produção de um inventário ou testamento familiar, seja diante de uma autoridade competente. Raphael Bluteau indica a presença da palavra no vocabulário romano. Ela era usada quando se deixava de mencionar os bens que se possuía ao censor. Essa declaração tinha por objetivo construir as listas de cobrança de tributos. Essas relações, normalmente, eram produzidas para determinar as cotas a serem pagas referentes aos impostos diretos, ou seja, que incidiam sobre os bens e a produção. Esse mecanismo foi o empregado na cobrança do donativo do dote e paz em algumas capitanias, como em Pernambuco. ${ }^{40}$ 


\section{REVISTA ANGELUS NOVUS}

A compreensão de que essa prática era ilícita não deixa dúvidas. Além da punição prevista nas Ordenações - deveriam perder as coisas e pagarem em dobro -, há várias repreensões dispersas pelo conjunto documental analisado. Esse verbo transitivo carregou no tempo o sentido de negar-se a fazer menção a algo obrigatório, e igualmente, como o ato de ocultação de forma fraudulenta. Assim, podia ser usado sempre que as atitudes dos agentes da colonização pudessem colocar em risco os interesses da Coroa.

Vejamos o furto das fazendas de Gaspar de Oliveira Vidigueira por Jacinto Pereira. Em um primeiro momento, a orientação do Conde de Autoguia parece fruto de uma típica preocupação com os bens de um leal vassalo ultramarino. Todavia, investigando um pouco mais, podemos compreender que havia mais coisa em jogo. Apesar de Gaspar Vidigueira não compor a nobre linhagem de Vasco da Gama - primeiro Conde de Vidigueira - seus negócios interessavam aos grandes do reino e à monarquia, uma vez que estava ligado ao corte e venda de pau-brasil e por ter sido representante do contratador do pau-brasil Luis Vás de Rezende. Mesmo a carta do Conde de Autoguia não tendo discriminado quais foram as fazendas e embrulhos roubados do barco, há a possibilidade de tratar-se de um monopólio régio e bens de um Fidalgo da Casa de Sua Majestade e Cavaleiro Professo no Hábito da Ordem de Avis. ${ }^{41}$

A estreita relação entre o ato de sonegar e os interesses régios pode ser verificada, todavia há uma baixa frequência e a dispersão temporal da aplicação da palavra sonegar e suas flexões. Diante disso, propomos uma digressão com vistas a elucidar as práticas às quais essa palavra buscava se referir. Rompendo com nossas premissas temporais, encontramos o emprego do vocábulo “sonegar” em regimentos e provisões. Nesse ponto da pesquisa, é bastante justificável realizar esse movimento, uma vez que eles eram expedidos novamente com pouquíssimas modificações, como evidenciou o clássico trabalho "Fiscais e Meirinhos". ${ }^{42}$

No primeiro regimento dos provedores do Brasil é possível localizar a previsão de punição para os casos de sonegação de direitos régios. É interessante notar que o método proposto para a averiguação da sonegação consistia na comparação dos montantes de açúcar declarados para o dízimo e o montante que circulou pelas alfândegas. ${ }^{43}$

4 I DHBN. Rio de Janeiro: Biblioteca Nacional, v. 3 p. 346-247, 1928. DHBN. Rio de Janeiro: Biblioteca Nacional, v. I6, p.II2-II5, 1930. DHBN. Rio de Janeiro: Biblioteca Nacional, v. 16, p.422- 427, 1930.

42 SALGADO, G. Fiscais e meirinhos. A administração no Brasil Colonial. Rio de Janeiro: Nova Fronteira, 1985.

43 DHBN. Rio de Janeiro: Biblioteca Nacional, v. 36, p. 20I-231, 1937. Consta também em DHBN. Rio de Janeiro: Biblioteca Nacional, v. 78, p. 234-262, 1947.

I8 • ano XII, n. 17, 202I • ISSN 2I79-5487 
A princípio, a metodologia parece muito coerente, uma vez que, o açúcar era um produto essencialmente destinado à exportação. $\mathrm{O}$ envio para os portos era feito em caixas de madeira, lacradas e marcadas com o nome do produtor e com a quantidade de arrobas correspondentes. Tudo deveria ser lançado no livro das alfândegas. Esse compêndio poderia ser comparado com as declarações constantes nos livros dos dízimos. Lembrando que esses eram produzidos a partir da verificação nas fazendas, faz sentido a avaliação. O problema estava na prática tributária. Começando pela determinação do valor a ser pago pelo dízimo. Era comum que esse fosse definido através da capacidade produtiva do engenho ou da lavoura. Isso significa dizer que o pagamento do dízimo era definido a partir da quantidade de escravos de um produtor e não do que de fato havia produzido.

Como sabemos, o dízimo era arrematado, por isso os livros da arrecadação ficavam em posse dos contratadores que, quando prestavam contas, o faziam em um período nunca menor do que três anos. Já os livros da alfândega, nem sempre existiam, ou, quando existiam, nem sempre sobreviveram às precárias instalações alfandegárias.

A manutenção e o acesso aos livros de controle das receitas e despesas parecem ser um problema constante. Os desembargadores responsáveis pela fiscalização e pela cobrança do donativo do dote e paz de Holanda em diferentes capitanias do Estado do Brasil pareciam nadar contra a corrente. As oposições vinham da Câmara, da provedoria, do governo, de todos os lados. À dificuldade de acesso aos livros somava-se a ausência de ordenação lógica. Joseph de Freitas Serrão não conseguia identificar a origem de cada recurso listado. Como alegava o juiz: "Este dinheiro consta de tão miúdas adições, que me não é possível individualizar, a quem cada um pertence”. ${ }^{44}$

Em I673, as diligências de Sebastião Cardoso Sampaio estavam atrasadas, pois o provedor da fazenda relutava em entregar os livros e demais papéis ao desembargador. ${ }^{45}$ João de Góis de Araújo não encontrou menos dificuldades para ter acesso aos papéis da receita e despesa do donativo do dote e da paz de Holanda. Depois de uma cena típica de romance policial, com constrangimentos, interrogatórios e buscas em todas as partes da Câmara, por fim conseguiu que Domingos Dantas revelasse onde estavam os livros e cadernos. Os documentos foram encontrados na casa do próprio. ${ }^{46}$

Os livros circulavam e eram retidos a favor das vontades individuais e dos jogos de interesses entre os grupos. Essas situações evidenciam o inegável poder que a posse dos

\footnotetext{
44 AHU. Luisa da Fonseca. Salvador, 26/05/1692. Bahia, doc. 3699.

45 SCHWARTZ, S. Burocracia e sociedade no Brasil Colonial. São Paulo: Companhia das Letras, 20II, p. I40. AHU. Livro de registro de cartas régias e avisos dirigidos ao governador do Brasil e outras entidades sobre diversos assuntos, Códice 245. Lisboa, I5/09/1673. f. 8v.

46 AHU. Luiza da Fonseca. Bahia, 20/o1/1668. Bahia, Doc. 2235.
} 


\section{REVISTA ANGELUS NOVUS}

livros dava ao seu possuidor, seja sobre quem pagava, ou em quem era aliviado, ou mesmo, na forma de dispor o que se tinha arrecadado. Tal dinâmica não era específica ao donativo do dote e paz, mas aos mais diversos recursos fazendários. Vejamos a situação dos direitos do açúcar.

No início do século XVII, quando a Coroa portuguesa estava sob o domínio do Rei Felipe II, André Farto da Costa investigava as denúncias sobre a sonegação dos direitos do açúcar, no valor de, aproximadamente, sessenta mil cruzados. Perseguir os rastros dessa importante renda não foi tarefa fácil. ${ }^{47}$ Desde 1612, Farto da Costa, que já deveria estar farto de averiguar livros mal escritos, com páginas faltantes ou corroídas por traças e cupins, ainda ouvia imensas desculpas de todas as partes sobre as certidóes dos direitos e as declarações sobre as receitas que nem chegavam às suas mãos. ${ }^{4}$

Apesar de ter conseguido aumentar a receita da Câmara de Salvador em cerca de cinco mil cruzados, passando a arrecadação de três mil para mais de oito mil, Fardo da Costa estava cansado e desabafava: "quando se intenta fazer alguma execução me põem a mim a culpa e provocam os homens a ira contra mim, dizendo que sou a causa de mais se lhe pedir o que em si tinham por seu, e que vim a destruir este estado”. ${ }^{49}$

A Coroa estava ciente da possibilidade de os agentes coloniais deixarem de declarar sua produção a fim de pagar menos tributos, direitos e impostos. Tal atitude era encarada não apenas como um ato ilícito passível de punição régia, era, mesmo, vista como um pecado. Podemos perceber essa acepção através do conjunto de provisões e alvarás emitidos para a atuação e autoridade de João Dias como Clérigo de Missa na Igreja de Santa Cruz em Ilhéus. Ao Cura era atribuído o poder de dar todos os sacramentos e absolver de todos os pecados, exceto nove. Entre eles figuravam os pecados de considerável importância, como, por exemplo, o de assassinato fora da guerra justa e o de sonegação. Cabia à autoridade superior dar perdão ou penitência quando ocorresse sonegação acima de trezentos reis ou quando os dízimos não pagos passassem desse valor..$^{\circ}$

Em uma tentativa de transpor a relação entre o prejuízo e o pecado em números, podemos concluir que a tolerância ao pecado era muito pequena. Tomando por base o valor de cada arroba de açúcar - I\$200 réis para o ano de 1663 - qualquer sonegação

47 As Juntas da administração e arrecadação da Real Fazenda foram mais comuns entre I760 e I770, todavia, em momentos anteriores podemos identificar o que podemos chamar de juntas ad hoc, ou seja, grupos de trabalho criados para funções e tempos determinados.

48 AHU. Pernambuco, Cx. I, Doc. 49. 03/o2/16ı6. AHU. Lisboa, I4 de Setembro de I6I2. Bahia, cx. I, doc. 34 AHU. Lisboa, 8 de outubro de I6ı2. Bahia, cx. I, Doc. 37. BIBLIOTECA NACIONAL. "Livro da Junta de Arrecadação da Fazenda Real”. In: DHBN. Rio de Janeiro: Biblioteca Nacional, v. 2, I928.

49 AHU, Bahia. Caixa I, doc., 68-69.

5o DHBN. Rio de Janeiro: Biblioteca Nacional, v. 35, p. 424-426, 1937.

$20 \cdot$ ano XII, n. I7, 202I $・$ ISSN 2179-5487 
maior que cinco quilos de açúcar necessitava do perdão de uma autoridade "mais digna". ${ }^{\text {sI }}$

De qualquer maneira, sonegar era um pecado, portanto, digno de penitência, mas também de perdão. E quando coubesse punição essa deveria ser feita de modo a não levantar os povos. $\mathrm{O}$ conde de Vimeiro recebeu louvor por colocar a arrecadação da fazenda real e da Câmara em dia, bem como por buscar restituí-la do que havia sido sonegado. Ao mesmo tempo, foi advertido para nestas matérias tratar "com suavidade os povos" agindo "sem opressão, nem violências". Continuando, o Conselho Ultramarino ponderava sobre os procedimentos do Conde, apelava para o uso da boa razão como princípio básico para ser mais bem-aceito e não provocar o clamor popular. Lendo nas entrelinhas, podemos supor que Vimeiro procedia com mais temor do que amor e era, como vimos, advertido por isso..$^{22}$

Os conflitos gerados pela sonegação nos levam a um arranjo bastante interessante. Antonio Dorta aparece como suspeito de uma série de procedimentos ilícitos ocorridos na provedoria da fazenda da capitania do Espírito Santo. Entre os problemas estão a sonegação de 40 moios de sal e mais de 60 pipas de vinho. A suspensão do donativo do vinho naquela capitania teria sido um atrativo para o comércio dessa bebida. Contudo, constava nos livros da alfândega que apenas 40 pipas passaram pelo porto. A perspectiva de prejuízo para a Fazenda Real estava na casa dos dois mil cruzados.

A suspeita recaía sobre Antonio por uma série de fatores: o cargo que ocupava; a sua "nação"; suas dívidas com o contrato do dízimo dos últimos seis anos; o círculo de relacionamentos. A lista é formada por argumentos de ordem prática e moral. O cargo ocupado por Antonio Dora lhe permitia acesso direto ao controle da circulação das mercadorias, bem como às rendas da fazenda real, criando a oportunidade de sonegar. Há uma aparente semelhança dos procedimentos com os atuais, um mau pagador não era digno de muitos créditos. Não pagar o contrato dos dízimos, na maioria das vezes, significava ter recolhido o imposto e não repassar a parte da Coroa. Logo, sonegava aqui também.

Em uma sociedade tradicional, o indivíduo não era visto por si mesmo. Suas relações pessoais, sua origem, raça ou nacionalidade estavam recobertas de julgamentos e preconceitos. Seu parentesco com Simão Luiz que tinha dívidas com a Coroa contava negativamente para a avaliação de sua pessoa. Como homem da "nação", ou seja, como hebreu, sua existência a priori carregava de valoração negativa. Acompanhado de mais opulencia do Brasil por sua Drogase Minas. Belo Horizonte: Itatiaia/Edusp, 1982, p. 237. 


\section{REVISTA ANGELUS NOVUS}

dois "homens de nação" no governo, Antonio podia mesmo ser visto como integrante de uma "quadrilha". Diante de tudo isso, orientou-se ao o desembargador Manuel Pereira Franco a averiguar todos os envolvidos na questão. ${ }^{53}$

A missão foi cumprida, ao menos em parte. Manuel Pereira Franco esteve no Espírito Santo tomando os depoimentos de testemunhas contra o capitão Manuel de Almeida do Canto, acusado na mesma carta citada acima de ter tido gastos excessivos com os soldados. ${ }^{54}$ Essa despesa será por vezes avaliada como fraudulenta, como veremos mais a frente.

Dissemos em parte, pois não encontramos indicações de que toda a ordem tenho sido cumprida. Os fundos pesquisados não possuem documentos a respeito das investigações sobre os moios de sal e pipas de vinho. Mas os silêncios das fontes podem ser sugestivos. Ou a investigação ocorreu e a documentação foi perdida, ou, simplesmente, não aconteceu. $\mathrm{E}$, sendo essa a realidade, qual seria a razão para o desembargador seguir uma ordem e não outra? Vejamos um pouco mais sobre Antonio Dorta.

Nosso personagem teve uma vida relativamente documentada e bem interessante. Oito anos antes de ser suspeito de sonegar vinho e sal, Antonio Dorta foi parar nos cárceres acusado de inconfidência. A denúncia informava que o denunciado havia dito que "D. João IV, era rei de copas ou de comédia”, felicitando, em sequência, os louros do reinado de Felipe III. Mesmo preso, Antonio mantinha seu potentado e ria-se de todos, como alegou o capitão-mor do Espírito Santo.

Debochado e descrente das capacidades do monarca, Dorta não hesitou em continuar servindo, nem tão pouco de solicitar mercês ao "rei de copas". Dois anos após a prisão, arrematava o contrato dos dízimos, e mais seis anos depois já estava ocupando o cargo de provedor da alfândega do Espírito Santo. Mais algum tempo depois conseguiu a propriedade do ofício de provedor da alfândega para nomear qualquer um dos seus filhos. 55

Diante da trajetória administrativa de Dorta, podemos concluir que tendo sido preso como "inconfidente", sendo homem da nação, ou talvez, mesmo tendo sonegado e corrompido a coisa pública, Antonio Dorta colheu os louros de sua atuação como contratador dos dízimos e provedor da alfândega. De alguma maneira, suas ações lícitas e ilícitas permitiram, ou mesmo não impediram, os fluxos financeiros e políticos entre o reino e o ultramar. Provavelmente, as perdas justificavam-se diante dos ganhos.

\footnotetext{
53 DHBN. Rio de Janeiro: Biblioteca Nacional, v. 4, p. 438-440, 1928.

54 AHU. Avulsos da Bahia.Espírito Santo, II/o9/1649. Cx. 5, doc. 1343.

55 AHU, op. cit, doc. 1343
}

$22 \cdot$ ano XII, n. I7, 2021 • ISSN 2I79-5487 
Portanto, concordamos com Paulo Cavalcante, no descaminho podia ser realizado o caminho.

O caminho também podia ser desviado. No dicionário de época utilizado, há entre as práticas desviantes, o extravio de dinheiro e fazenda: "Fazia trazer publicamente muitas cousas para a sua casa; secretamente desviava muitas mais". ${ }^{6}$ Evidentemente, a sentença exprime um ato ilícito. $\mathrm{O}$ que nos leva a apurar seus usos em nosso corpus documental.

Em primeiro lugar, cabe dizer que localizamos 107 repetiçóes do substantivo desvio e do verbo desviar. Desse conjunto, a maioria absoluta está fora do nosso recorte temporal, ou temático, pois se refere ao desvio de uma rota, de uma estrada, de um trajeto. Sobram somente onze documentos a serem analisados de forma mais atenta. Em segundo lugar, não restam dúvidas de que as fontes selecionadas estão nomeando práticas contrárias às normativas régias. Em todas essas situações, buscava-se prevenir ou investigar os desvios de mercadorias ou dinheiro, seja no comércio ou no pagamento de tributos.

Ao menos um dos onze documentos problematizou o envio de produtos para destinos não autorizados pela Coroa. Na década de 1720, Vasco Fernandes Cesar de Menezes solicitava ao rei uma investigação sobre o desvio de tabacos de Pernambuco para a Costa da Mina. Roquinaldo Ferreira estudou esse comércio ilegal, indicando a importância do mesmo para garantir o fluxo de escravos necessário às minas. Provavelmente, por essa razão, as várias solicitações de Menezes para "dar providência mui eficaz para se remediar este descaminho" não foram atendidas. ${ }^{57}$

A casa da Alfândega do Rio de Janeiro volta a aparecer. O Conselho Ultramarino atestava que o tamanho do lugar criava oportunidades de desvio. A solução proposta foi colocar a Alfândega no grande armazém da Junta do Comércio. Novamente, o espaço aparece como causa e solução do problema do descaminho. Todavia, pasmem, falava-se a essa altura da nova casa da alfândega, construída durante o governo de Aires Saldanha.

Um ano antes, Luis Vahia Monteiro havia descrito a Alfândega como inapropriada, possuindo várias portas. Se essas portas facilitavam o desvio das mercadorias e a sonegação dos tributos, na avaliação do governador os contínuos furtos, na calada da noite ou mesmo em plena luz do dia, ocorriam com a conveniência ou mesmo participação das sentinelas. Assim, mais do que o espaço, o motor para os desvios eram as possibilidades de ganhos extras que as partes envolvidas podiam

56 BLUTEAU, op. cit., v.3, p. 183.

57 DHBN. Rio de Janeiro: Biblioteca Nacional, v. 98, p. 56, 1958. 
REVISTA ANGELUS NOVUS

conseguir..$^{8}$ Os sentidos e usos de desviar nos remetem ao nosso último vocábulo: descaminho.

\section{$\mathrm{O}$ ato de descaminhar}

De diferentes formas e com uma recorrência considerável, os regimentos, cartas, portarias e provisóes costumavam conter a máxima "para que não haja o menor descaminho". Rafael Bluteau associava o descaminho a um conteúdo moral. Descaminhar era ato cometido por uma Immoderata licencia e Vita dissolutior, ou seja, por quem vivia de forma desmedida, relaxada, corrupta, depravada. Também descaminhava, saía do caminho, aquele que desviava o dinheiro da República. Em verdade, asseverava Bluteau, essa prática era um delito contra seu amo. 59 Portanto, é essa a expressão que nos ajuda a identificar o tipo de prática que estamos buscando investigar. Observemos os números da pesquisa no tocante aos termos que remetem às práticas ilícitas.

As ações em questão totalizam I862 citações, dais quais quase $80 \%$ são nomeadas como descaminhos, descaminho e descaminhar. A título de amostragem, selecionamos os I84 casos de uso do substantivo no singular presente na Coleção. Desse conjunto, $60 \%$ remontam ao século XVIII. O maior volume pode estar relacionado a alguns fatores com a maior proximidade temporal, o crescimento populacional, o incremento de uma cultura escrita, a maior dispersão territorial das atividades econômicas, mas, inegavelmente, à descoberta do ouro. Alvo privilegiado das diversas práticas ilícitas.

Os documentos inseridos no nosso recorte temporal totalizam 137 , abordando a questão fiscal e o contrabando. Desse universo, podemos dizer que is nos permitem problematizar, sem sombra de dúvidas, ambos os temas. Ainda que um produto contrabandeado dificilmente contribua para o fisco régio, fizemos aqui essa distinção: vamos atentar para os documentos em que há menção direta às perdas fiscais. O contrabando e o comércio ilegal surgem a partir desse critério. Portanto, passaremos a analisar os 70 documentos restantes. ${ }^{60}$

O que procuramos nesses documentos? Data de ocorrência, tipo de tributo, ação preventiva ou investigativa, punições ou perdões. Assim, temos 36 circunstâncias

58 OLIVEIRA JR e CARDOSO, op. cit., p. 52.

59 BLUTEAU, op. cit., v. 4, p. 205.

6o Cabe dizer que infelizmente, não foi possível contemplar as variações nominais e verbais do termo, que como pode ser visto na tabela I, triplicaria essa consulta. Igualmente, contemplamos poucas fontes do projeto resgate, uma vez que desde o princípio, sua inclusão nesta pesquisa foi com o objetivo de complementar e aprofundar as questões suscitadas pelos documentos da coleção documentos históricos.

$24 \cdot$ ano XII, n. 17, 2021 ・ ISSN 2179-5487 
dedicadas à prevenção de descaminhos da Fazenda régia, e 34 contendo orientações ou ordens para que sejam realizadas investigações.

A existência de uma preocupação da Monarquia em combater as práticas ilícitas é o que torna essa pesquisa viável. Uma possível falta de interesse da Coroa em não conter, punir ou mesmo em conceder o perdão aos "descaminhadores”, reduziria drasticamente os registos sobre os atos.

Dessa atuação fiscalizadora da metrópole temos inscrita na memória de grande parte dos brasileiros uma clássica imagem ligada aos descaminhos: o santo do pau oco. Esculturas de madeira ocas por dentro, recheadas de ouro por quintar circulavam pelas estradas até os portos, seguindo na calada da noite, para os navios. Perdia assim a Coroa seus quintos e o Brasil seu rico mineral. Para Paulo Cavalcante, se para a Fazenda Real essa prática implicava a perda de direitos, caracterizando, portanto, ilícito fiscal, ao fim e ao cabo, ao ouro realizava seu caminho, era extraído da colônia e seguia para a Europa. O sentido da colonização, cumpria-se. ${ }^{61}$

O imaginário relaciona o ilícito ao período noturno, mas a experiência revelou a necessidade de manter sentinelas por toda a praia de dia e de noite. ${ }^{62}$ Os atos ocorriam mesmo a luz do dia e tornavam-se públicos provocando queixas dos povos. Como noticiou o cabido da sé do Rio de Janeiro ao Conselho Ultramarino em julho de I7oI, os frades que andavam nas minas de ouro agiam em seu próprio favor sendo "poucos os religiosos a quem se podia encomendar o exercício do bem espiritual das almas”. Os religiosos agiam contra Deus e contra a Sua Majestade. Em oposição aos interesses régios, "divertiam os quintos do ouro", ou seja, descaminhavam. Os conselheiros recomendavam uma seleção mais criteriosa dos missionários enviados para as minas, indo apenas aqueles que fossem "revestidos daquela virtude que é necessária, para que sirvam mais de exemplo do que de escândalo”. Para os outros religiosos sem licença, esses deveriam ser enviados, imediatamente, para o Rio de Janeiro. ${ }^{63}$

Interessante notar a ausência de uma recomendação punitiva aos frades descaminhadores, ou mesmo de uma orientação para averiguação do relato. Tais ausências contrastam o interesse com que os conselheiros trataram a questão. A discussão, segundo consta, foi iniciada no mesmo dia em que o procurador do cabido apresentou a carta ao tribunal e os conselheiros afirmam que se tratava de negócio de muita importância, necessitando de "toda vigilância”, cabendo evitar “não só as ofensas de Nosso Senhor, mais a atalhar-se os danos que se podem seguir nos descaminhos dos

\footnotetext{
6I OLIVEIRA JR., op. cit.

62 DHBN. Rio de Janeiro: Biblioteca Nacional, v. 98, p. 44-45, 9938.

63 DHBN. Rio de Janeiro: Biblioteca Nacional, v. 93, p. I26-I28, I95I.
} 


\section{REVISTA ANGELUS NOVUS}

quintos”. Os privilégios dos membros do clero dificultavam ou mesmo impediam a imputação de penas leigas sobre os seus atos, tornando-os parceiros cobiçados nos negócios de trapaça.

Grazielle Cardoso e Renata Ávila atestaram o envolvimento de membros da ordem beneditina em uma ampla gama de descaminhos e demais ilicitudes. Os personagens investigados por elas, quando acusados da prática de descaminhos ou outras ilicitudes, recorreram das penas e foram inocentados. Assim, podem ser caracterizados como astutos articuladores, estrategistas que souberam muito bem usar de sua inteligência para fazer com que os ventos soprassem a seu favor. ${ }^{64}$

As medidas para conter os descaminhos não remetem somente ao período da mineração. Assim, encontramos um alvará de 1657, pelo qual se ordenava a criação de regimentos, livros e cadernos, principalmente, na Câmara referentes a toda a arrecadação executada ou administrada pelos oficiais. Pois, o registro evitaria "qualquer descaminho dos que pode ocasionar a confusão e a falta de ordem (...)”. Todavia, nem todas as câmaras contavam com esse acerto, orientava-se aos moradores, para seguirem o exemplo da Câmara de Salvador. Novamente, a situação do registro dos tributos aparece como um traço característico dessa administração fiscal. ${ }^{6 s}$

Outra orientação com o objetivo de evitar o descaminho nos chamou a atenção. Quando uma figura fiscal estava sujeita a desvios e seus processos para combatê-los eram morosos demais, a Coroa ordenou que a renda fosse colocada em pregão. No início do ano de 1684, o Chanceler da Relação da Bahia, João de Sepúlveda e Matos informava sobre a baixa arrecadação da dízima, atribuindo a essa situação a falta de um executor "que aprecie a cobrança” e a pouca vontade com que agiam os escrivães em tirarem os processos. Relata ainda a ausência de um meirinho para fazer as execuções e o descaso dos juízes em satisfazer a cobrança. Com isso, os descaminhadores livravam-se de suas culpas e a fazenda real deixava de arrecadar cinco mil cruzados. ${ }^{66}$

A proposta do desembargador para admitir oficiais remunerados destinados a executar as cobranças foi ponderada pelo Procurador da Fazenda. O mesmo assevera contra o desembargador, lembrando "que suposta a omissão que o Chanceler apontava e que ele poderá remediar castigando os escrivães e meirinhos que fossem negligentes ou

64 SOUZA, J. V. A. Para além do claustro: uma história social da inserção beneditina na América portuguesa, c. I580-c.1690. Tese (Doutorado) - Universidade Federal Fluminense, Instituto de Ciências Humanas e Filosofia, Departamento de História, 2oir. ÁVILA, R. E CARDOSO, G. "O Envolvimento De Beneditinos Com Descaminhos e Demais Ilicitudes: Rio De Janeiro (1702-1729)”. In: Angelus Novus, São Paulo, no 6, p. II5-42, 2014 .

65 DHBN. Rio de Janeiro: Biblioteca Nacional, v. 5, p. 264-267, 1928. DHBN. Rio de Janeiro: Biblioteca Nacional, v. 5I, p. 183-184, 194I.

66 DHBN. Rio de Janeiro: Biblioteca Nacional, v. 89, p. 16-17, 1950.

$26 \cdot$ ano XII, n. 17, 2021 • ISSN 2179-5487 
maliciosos”. Mas tanto o Procurador, como o Conselho Ultramarino concordavam que "o melhor meio seria mandar que este direito das dízimas se contratasse a arrendar". Esse seria o único meio de fazer os recursos seguirem seu curso esperado, a Fazenda Real.67

As dízimas podiam ser da alfândega, do foro das terras dadas em sesmaria, do tabaco, do pescado, entre outras. Ao tomarmos o lugar de fala de João de Sepúlveda, Chanceler da Relação, podemos supor que o caso em análise, remeta à dízima da chancelaria. Segundo Angelo Carrara, essa teve seu regimento emitido em 25 de setembro de 1655 . A renda deveria ser destinada ao custeio das despesas judiciais.

Tal como ordenava a lógica fiscal da época, uma renda era criada a partir de uma despesa, devendo seguir consignada a ela. Todavia, nem sempre esse princípio imperava, pois não faltam situações em que usos dos recursos não correspondiam com as motivações iniciais. Com a dízima não foi diferente. Em uma busca rápida na Coleção Documentos Históricos, vemos algumas ocorrências dessa dinâmica. Em 1678, o dinheiro da dízima foi usado para comprar índios de resgate, sela para cavalos e como ajuda de custo para o capitão Francisco Fernandes Pacheco. Todos os gastos tinham por objetivo final custear a jornada às minas de salitre. ${ }^{68}$

Essas ordens sugerem que os recursos adquiridos através da cobrança da dízima da alfândega estavam disponíveis e sob o controle do Tesoureiro Geral. Tal situação, não permite afirmar se a essa época os impostos estavam arrematados ou não, pois cabia ao contratador entregar ao tesoureiro geral os rendimentos do contrato. $\mathrm{O}$ primeiro indício de arrematação foi indicado por Angelo Carrara. O historiador afirma haver uma carta régia de fevereiro de I68I, pela qual já era ordenado o arrendamento desse tributo. ${ }^{69}$

A lacuna entre as duas deliberações é bastante interessante. Teriam os oficiais ignorado as orientações metropolitanas e não colocado o contrato em pregão? Ou esse não teria encontrado interessados? Ambas as situações podem ter ocorrido. Para a Bahia encontramos contratos do imposto em questão para os anos de 1750 e 1767 . Em Pernambuco, o contrato encontrado data de dezembro de I8oo. Para o Rio de Janeiro, a arrematação refere-se também à segunda metade do século XVIII. ${ }^{\circ}$

Rastreando um pouco mais a dízima da chancelaria, encontramos uma série de nomeações para diversos cargos no sentido de efetuar a cobrança dos efeitos atrasados.

\footnotetext{
67 DHBN. Rio de Janeiro: Biblioteca Nacional, v. 89, p. 16-17, 1950.

68 DHBN. Rio de Janeiro: Biblioteca Nacional, v. 32, p. 93 e 99, 1936.

69 CARRARA, A. A. op. cit., p. 59-60.

70 AHU, Cx. I02, Doc. 8086 e 1767; AHU, Cx. 158, Doc. 12052.
} 


\section{REVISTA ANGELUS NOVUS}

Em I2 de dezembro de 17 I2 foi nomeado o desembargador Rodrigo Rabelo da Silva. Em agosto do ano seguinte foi a vez de Mateus Dias da Silva como meirinho e Braz de Fonseca como seu escrivão. Mateus Silva será substituído por Manuel Afonso da Costa, ainda antes da equipe partir para o sertão. ${ }^{71}$

No ano de 1729, a dízima foi mais um motivo de tensão entre os oficiais da Câmara, o governador e os moradores da capitania dos mazombos. ${ }^{72} \mathrm{O}$ governador escreveu ao rei denunciando os vereadores da Câmara de Olinda e praça de Recife por permitirem que depois do acordo já feito os procuradores da dízima acrescentassem um valor a mais ao contrato. Acusava-os, também, de permitir que cobrassem dívidas atrasadas. A primeira postura dos camarários lesava a Fazenda Real, pois os rendeiros arrendavam o contrato com a Coroa por um valor, mas com a permissão dos oficias da Câmara acabavam arrecadando mais, sem repassar qualquer parte do referido ganho à Fazenda Real. A segunda vexava os povos, pois a natureza dessa figura fiscal não permitia tal atitude.

Como consta na correspondência enviada ao Vice-rei Conde de Sabugosa, a "dita dízima da chancelaria, que é uma pena imposta ao que faz má demanda, e não direito real”, deveria ter um preço limitado pelo que se contratou. A deliberação régia foi pela anulação do contrato e suspensão das dívidas pretéritas, pois, afirmava o monarca, "sou servido perdoá-las”. Aqui a tipologia da imposição acabou por definir a dinâmica fiscal, ou seja, a teoria interferia na prática. ${ }^{73}$

Além disso, a questão em tela indica mais dois pontos sobre a dinâmica fiscal. Primeiro, podemos notar que mesmo não sendo possível encontrar um contrato da dízima da chancelaria, a presença de contratadores evidência a existência desse procedimento. $\mathrm{Na}$ carta régia citada acima, há ainda a orientação para fazer uma nova arrematação separando os contratos de cada capitania. Por último, ao contrário da expectativa régia, os contratos não reduziam os descaminhos em si e os devedores da dízima continuavam lesando a Fazenda Real, todavia esse prejuízo era, através desse mecanismo, dividido entre a Monarquia e os contratadores.

Retomemos aqui a questão em torno do não pagamento ou dos descaminhos das rendas fiscais e a punição/o perdão. Na vila Nova da Rainha os tumultos contra a forma de lançamento dos quintos a partir das bateias foi perdoado, pois se era considerado "certo também que todo o mineral ou seja ouro, prata, predaria, etc., se devem com

7I DHBN. Rio de Janeiro: Biblioteca Nacional, v. 5o. p. 72-73 e 77, 1940.

72 MELLO, E. C. Olinda restaurada. Guerra e açúcar no Nordeste, 1630-1654. São Paulo: Ed. $34,2007$. .Rubro Veio. O imaginário da restauração pernambucana. Rio de Janeiro: Nova Fronteira, 1986;

Fronda dos Mazombos. Nobres contra mascates. Pernambuco I666-I7I5. São Paulo: Ed. 34, 2003.

73 AHU. Recife, II de Junho de i729. Pernambuco, cx. 38, doc. 3444.

$28 \cdot$ ano XII, n. I7, 2021 $\bullet$ ISSN 2179-5487 
justiça e consciência os quintos a El-Rei como verdadeiro e Real Senhor”, todavia preocupava aos envolvidos definir uma forma de cobrar e de serem pagos "sem descaminho e com suavidade". ${ }^{74}$

Os mecanismos para conter os descaminhos esbarravam em uma série de desafios. Combater a circulação de ouro não quintado, por exemplo, dependia de uma cadeia de indivíduos mais ou menos comprometidos com os objetivos da Coroa. Tal situação pode ser evidenciada na correspondência do governador do Rio de Janeiro, Luis Vaia Monteiro. Segundo o governador, seus esforços em conter o descaminho foram em vão pela fraqueza de um sargento. Em uma emboscada na qual se tomaria uma grande quantia de ouro, em posse de Manuel Lopes, os soldados trocaram alguns tiros, mas logo fugiram com a ordem do sargento. Para Vaia Monteiro, "porque semelhantes fraquezas e os desinteresses e pouca eficiência das diligências são as causas de se não evitarem tão grandes roubos".75

Os roubos podiam não ser evitados, mas como a historiografia tem mostrado, alguns homens foram devassados, julgados e condenados. Obviamente, só sabemos da existência desses crimes, porque havia o interesse da Coroa em reduzir os danos. Em trabalho recente, Lincoln Marques analisa uma série de devassas arquivadas na Biblioteca Nacional, referentes ao contexto da mineração do século XVIII. O historiador identifica "um certo ritual jurídico, onde ocorria uma considerável descrição do crime, assim como, onde e quando ocorreu, além de quais foram as motivações ligadas a tal prática”. Segundo o autor, todos os processos envolveram homens que podiam ser militares, comerciantes, viajantes ou membros da administração. As origens sociais eram variadas, pobres, ricos, recém-chegados ou não. Alguns eram reincidentes. Quando havia condenação, a pena aplicada era o degredo e a perda dos bens. Todavia, em muitas situações, a apelação da defesa acabava por conseguir suplantar o degredo, argumentando que o réu desconhecia as leis locais ou que havia quintado o ouro em outra região. ${ }^{76}$

As referências aos descaminhos do ouro são recorrentes na documentação selecionada. Descaminhava-se o produto e o direito régio cobrado sobre ele. Vejamos agora outros dois gêneros de produtos que eram alvo de descaminhos. Tanto o tabaco como os negros eram objeto de ilícito fiscal e de contrabando. Cabe notar que no universo delimitado por essa pesquisa, o tabaco perde para o ouro com apenas uma

74 MONTEIRO, R. B. O Rei no Espelho. A Monarquia Portuguesa e a colonização da América. I640-I720. São Paulo: Hucitec, 2002.

75 DHBN. Rio de Janeiro: Biblioteca Nacional, v. 94, p. 75-76, I95I.

76 SANTOS, L. M. Governo, poder e fiscalidade: as Minas Gerais setecentistas nos domínios do Império Português (1700-1750). Pesquisa financiada pela Fundação Biblioteca Nacional, 2017. Aguardando publicação. 


\section{REVISTA ANGELUS NOVUS}

citação a menos. Evidentemente, o ouro era muito mais fácil de descaminhar, o alto valor das pequenas pepitas ou mesmo o pó, exigia poucos esforços para a sua ocultação. Igualmente, tratava-se de descaminhar a moeda em si. Ao contrário, os rolos de tabaco precisavam ser inseridos em uma rede comercial para o ganho ser realizado e, obviamente, para compensar os custos e possíveis danos, fazia-se necessário descaminhar uma boa quantidade, um volume considerável. ${ }^{77}$

No tocante ao comércio de escravizados, uma estratégia era retirar, nos portos da Bahia, Pernambuco e Rio de janeiro, as guias de pagamento dos direitos sobre os cativos, alegando enviá-los para as minas, mas vender as "peças” no litoral. Depois, costumavam repassar as guias a outras pessoas que introduziam mais escravizados às minas "livres de direitos". Assim, deixando de pagar os direitos correspondentes a cada cabeça. ${ }^{8}$

O relato acima nos permite encaminhar um último problema: a associação implícita entre contrabando de mercadorias e descaminho fiscal. Evidentemente, quando um dos muitos navios franceses aportava no litoral brasileiro e vendia escravos a peso de ouro, a Fazenda Real não arrecadava um centavo do direito dos escravos ou de outros tributos. Porém, nessa circunstância, se os franceses tivessem trazido uma mercadoria não sujeita a tributação haveria apenas contrabando e não lesaria diretamente a Fazenda Real. Isso porque contrabando pode ser entendido como o ato de importar ou exportar produtos proibidos ou, no período colonial, manter comércio com quem não tem licença para fazê-lo. Em ambas as circunstâncias não configurava, essencialmente, ilícito fiscal. ${ }^{79}$ Diante da dependência da Coroa Portuguesa em relação à circulação de mercadorias dificilmente um produto com valor de mercado não tinha uma tributação sobre ele. No geral, os monarcas estavam sempre preocupados com o contrabando, seja pela perda comercial para os mercadores portugueses, seja pela fissura em sua arrecadação alfandegária.

Portanto, quando usavam a mesma guia para enviar os escravos para as minas não estavam contrabandeando peças, pois o comércio de escravos era legal. Mas, estavam sim ocasionando perdas à fazenda real, portanto sonegando ao fisco. Diferente do envio de pau-brasil para São Thomé e para a Costa da Mina. Os mestres dos navios sabiam claramente que podendo navegar em direitura para a África não podiam levar o pau-

77 Dado o limite desse estudo e a própria característica dos documentos - dispersos e sintéticos - não vamos nos debruçar sobre esse caso.

78 DHBN. Rio de Janeiro: Biblioteca Nacional, v. 8o, p. 326-328.

79 Atualmente, o código penal brasileiro distingue os dois crimes, caracterizando o descaminho como o ato de frustrar o pagamento de direitos alfandegários ou impostos sobre consumo, e o contrabando como o ato de importar ou exportar produtos proibidos. REGIS, L. Direito Penal Econômico. São Paulo: RT, 2009, p. 305.

$30 \cdot$ ano XII, n. I7, 2021 $・$ ISSN 2179-5487 
brasil que era monopólio, sendo seu comércio exclusivo. Portanto, sem o arrendamento desse monopólio, incorriam no crime de contrabando, tanto quanto fiscal, pois afetavam diretamente as rendas da Coroa. ${ }^{80}$

Assim, encaminhamos as considerações finais desse trabalho indicando que o vocabulário fiscal era usado com sentidos diferentes dos atuais, não impedindo aproximações, nem tão pouco impossibilitando a sua compreensão. Todavia, é importante estarmos atentos aos termos e a seus usos. Como vimos, ao nomear a ordem com determinadas palavras abria-se brechas para debates políticos e reivindicações. Sentidos dicionarizados eram colocados como balizas para defesa dos súditos em relação ao ímpeto fiscal régio. Imposto, tributo e donativo podiam ser associados no cotidiano, todavia, em certas ocasióes, as diferenças eram colocadas.

Nos limites dessa pesquisa, averiguamos que a palavra corrupção tal como entendemos hoje, raramente era utilizada para dar conta das práticas que compreendemos como corruptas atualmente. Todavia, um outro conjunto de vocábulos buscava dar conta dessas atitudes desviantes, sendo inegável a predominância do termo descaminhos.

O descaminho implicava uma ampla categoria de comportamentos e práticas ilícitas que de diferentes formas acabavam por lesar a Fazenda Real. Entre elas destacamos: o repasse de guias de pagamento, os soldados fantasmas, a mudança dos termos dos contratos, os não registros ou mesmo a inexistência de livros e cadernos para fazê-los. Esses quando existiam eram mal escritos, com páginas faltantes ou corroídos por traças e cupins. Não lançar a movimentação das mercadorias ou a arrecadação dos tributos foi uma das estratégias mais comuns.

Vimos também algumas medidas implementadas pelos agentes régios, como a arrematação de contrato, o estabelecimento de inquéritos, o envio de sentinelas, nomeação de oficiais, obras na casa da alfândega e até mesmo um exame do caráter dos religiosos estiveram entre as pautas para conter os descaminhos.

A Coroa demonstrava e exigia de seus representantes ações para evitar quaisquer descaminhos. Estava preocupada, portanto, com os ganhos não institucionais angariados pelos homens de negócios, oficiais, senhores de engenho, ou quaisquer outros vassalos do mundo colonial. Principalmente, quando esses lesavam as rendas régias. Observemos, contudo, que havia uma tolerância significativa para com esses atos, havendo indicações de penas, mas também havia espaço para o perdão. Desse modo, com perdas e ganhos, fazia-se uma política fiscal descentralizada e dispersa pelo conjunto da sociedade e de suas atividades econômicas. Enquanto isso, a Coroa e os 
REVISTA ANGELUS NOVUS

agentes coloniais estavam atentos aos ganhos extras, mas principalmente em que medida esses ganhos lesavam a Real Fazenda.

$32 \cdot$ ano XII, n. 17, 2021 ・ ISSN 2179-5487 